\title{
Shifts in Zooplankton Community Structure: Implications for Food Web Processes in the Upper San Francisco Estuary
}

\author{
Monika Winder • Alan D. Jassby
}

Received: 24 March 2010 /Revised: 25 August 2010/Accepted: 29 September 2010 / Published online: 21 September 2010

(C) The Author(s) 2010. This article is published with open access at Springerlink.com

\begin{abstract}
Zooplankton are an important trophic link and a key food source for many larval fish species in estuarine ecosystems. The present study documents temporal and spatial zooplankton dynamics in Suisun Bay and the Sacramento-San Joaquin Delta-the landward portion of the San Francisco Estuary (California, USA) - over a 37year period (1972-2008). The zooplankton community experienced major changes in species composition, largely associated with direct and indirect effects of introductions of non-native bivalve and zooplankton species. A major clam invasion and many subsequent changes in zooplankton abundance and composition coincided with an extended drought and accompanying low-flow/high-salinity conditions during 1987-1994. In the downstream mesohaline region, the historically abundant calanoid copepods and rotifers have declined significantly, but their biomass has been compensated to some extent by the introduced
\end{abstract}

Electronic supplementary material The online version of this article (doi:10.1007/s12237-010-9342-x) contains supplementary material, which is available to authorized users.

\section{Winder $(\bowtie)$}

John Muir Institute of the Environment,

Tahoe Environmental Research Center, University of California,

Davis, CA 95616, USA

e-mail: mwinder@ucdavis.edu

\section{Winder}

Leibniz-Institute of Marine Sciences at Kiel University (IFM-GEOMAR),

Düsternbrooker Weg 20,

24105 Kiel, Germany

\section{A. D. Jassby}

Department of Environmental Science and Policy,

University of California,

Davis, CA 95616, USA cyclopoid Limnothoina tetraspina. The more upstream estuary has also experienced long-term declining biomass trends, particularly of cladocerans and rotifers, although calanoid copepods have increased since the early 1990s due to the introduced Pseudodiaptomus spp. In addition, mysid biomass has dropped significantly throughout the estuary. Shifts in zooplankton species composition have also been accompanied by an observed decrease in mean zooplankton size and an inferred decrease in zooplankton food quality. These changes in the biomass, size, and possibly chemical composition of the zooplankton community imply major alterations in pelagic food web processes, including a drop in prey quantity and quality for foraging fish and an increase in the importance of the microbial food web for higher trophic levels.

Keywords Zooplankton · Sacramento-San Joaquin Delta . Trophic interactions · Carbon biomass · Invasion . Copepods $\cdot$ Mysids $\cdot$ Limnoithona

\section{Introduction}

Water quality and fish production have declined in many estuaries over the last decades (Houde and Rutherford 1993; Sommer et al. 2007; Petersen et al. 2008; Paerl et al. 2010) as a result of multiple interacting stressors, one of which is reduced zooplankton productivity that provides forage for higher trophic levels (Kiørboe and Nielsen 1994; Verity and Smetacek 1996). Estuarine zooplankton is characterized by large abundance fluctuations, often associated with flow, salinity, and temperature changes driven by weather and climate (Kimmel and Roman 2004; Costello et al. 2006; Allen et al. 2008). Estuaries are also susceptible to invasion by non-indigenous species owing to exposure to extensive 
transport vectors (Cohen and Carlton 1998), which can greatly modify species composition and biotic interactions that result in remarkable abundance changes (Bouley and Kimmerer 2006). Long-term time series of biological variables now enable us to characterize estuarine zooplankton dynamics and their potential impact on upper trophic levels; yet, there have been few formal studies that describe decadal-scale trajectories of the total zooplankton communities in these systems (but see Zervoudaki et al. 2009; Verity and Borkman 2010).

Decreased prey availability has been hypothesized as a cause of long-term population declines of many pelagic fishes in Suisun Bay and the Sacramento-San Joaquin Delta, a complex of tidal waterways forming the landward portion of the San Francisco Estuary (California, USA). Declines of delta smelt (Hypomesus transpacificus), longfin smelt (Spirinchus thaleichthys), striped bass (Morone saxatilis), and threadfin shad (Dorosoma petenense; Feyrer et al. 2007; Sommer et al. 2007) were caused mainly by poor survival and growth of larval and juvenile fish (Bennett and Moyle 1996), which prey primarily on zooplankton (Moyle 2002; Kimmerer 2006). The decadalscale fish decline coincided with declines in phytoplankton and native zooplankton production, suggesting that zooplankton availability and quality played a key factor for fish recruitment (Jassby et al. 2002; Sobczak et al. 2002; Kimmerer 2004; Bouley and Kimmerer 2006; Cloern 2007). Substantial changes in zooplankton species composition and identification of species abundance trends have been described in the past for this estuary (Kimmerer and Orsi 1996; Orsi and Ohtsuka 1999; Kimmerer 2004; Bouley and Kimmerer 2006), and causal linkages for the decline in some native zooplankton species have been identified (Kimmerer 2005). Reduced production at multiple trophic levels also indicates that the capacity of the Delta to support fisheries may have significantly declined over the last three decades (Baxter et al. 2007; Cloern 2007).

The biota of this estuary was strongly shaped by various species invasions (Cohen and Carlton 1998). The suspension-feeding clam Corbula amurensis spread throughout the entire Delta after its introduction in 1986 (Nichols et al. 1990; Alpine and Cloern 1992) and largely suppressed phytoplankton production, although phytoplankton has rebounded in the upstream region since 1996 (Jassby 2008). The phytoplankton decline was accompanied by a shift in species composition from a diatom-dominated community to a higher proportion of chlorophytes, flagellates, and cyanobacteria (Lehman 2000). Substantial changes in zooplankton abundances and species composition due to numerous species invasions also occurred over the last decades of the twentieth century (Orsi and Ohtsuka 1999). The sampling period before 1990, even before the clam invasion, was characterized by declines in many zooplankton species in this estuary, including rotifers, cladocerans, copepods, and mysids (Kimmerer et al. 1994; Cloern 2007). Declines since the clam invasion have been attributed mainly to clam predation and reduced phytoplankton availability (Kimmerer et al. 2005). Zooplankton abundance declines have been compensated by the introduction of the cyclopoid copepod Limnoithona tetraspina in the early 1990s, which has become the numerically dominant copepod species (Bouley and Kimmerer 2006). The proliferation of C. amurensis and many subsequent changes in plankton abundance and composition coincided with an extended drought and accompanying low-flow/high-salinity conditions during 1987-1994.

More recent precipitous population declines in the Delta pelagic fishes since 2000 have created a new urgency for understanding zooplankton community changes (Feyrer et al. 2007; Sommer et al. 2007). In addition to updating the zooplankton species records, we need to understand their implications for the quantity and, to the extent possible, quality of total zooplankton carbon, the primary prey for larval fish. In the present study, we investigate zooplankton community dynamics over the last 37 years in the upper San Francisco Estuary and discuss the long-term and more recent behaviors in the context of environmental changes that occurred over the corresponding time periods. This is one of the longest, most complete estuarine zooplankton records available for the characterization of zooplankton community variability. We examine changes in total biomass, community composition, and size structure in different regions of the Delta, all of which we use to infer changes in the food supply to higher trophic levels, including the pelagic fishes currently at risk.

\section{Material and Methods}

\section{Site Description}

The San Francisco (SF) Estuary is the largest estuary on the US Pacific coast and provides important ecosystem services to the state of California, including drinking water for over 22 million people, irrigation water for one of the world's most productive agricultural centers, and open water habitat for 750 plant and animal species (CALFED 2001). Freshwater inputs are dominated by the Sacramento and San Joaquin Rivers, which provided on average $84 \%$ and $12 \%$, respectively, of the freshwater during 1969-2005 (IEP 2006); smaller tributaries contributed the remaining inflow. Flow rates exhibit considerable seasonal and annual variation and reflect wet winters and dry summers linked to large-scale climate oscillations. River flow in turn drives 
large fluctuations in the distribution of salinity, suspended particles, nutrients, and biota (Cloern and Nichols 1985; Jassby and Cloern 2000; Jassby et al. 2002)

The present study focuses on the upper SF Estuary (i.e., the Sacramento-San Joaquin Delta, an inverted river delta, plus Suisun Bay) which is a heterogeneous environment of tidal freshwater habitats, including channels, sloughs, shallow lakes, and estuarine embayments comprising about $2.7 \times 10^{8} \mathrm{~m}^{2}$ of open water habitat in the Delta (Jassby and Cloern 2000) and $1.0 \times 10^{8} \mathrm{~m}^{2}$ in Suisun Bay (Jassby et al. 1993). Allochthonous sources (mostly river inputs) account for an average of about $85 \%$ of the annual organic matter supply to the Delta; in contrast, internal primary production within the system accounts for about $15 \%$. Autochthonous primary production is dominated by phytoplankton, while production by macrophytes and benthic algae is relatively small (Jassby and Cloern 2000). Allochthonous sources probably account for an even higher proportion in Suisun Bay (Jassby et al. 1993). This turbid nutrient-rich estuary is a low-productive system with a mean annual primary production in the Delta of about $70 \mathrm{gCm}^{-2}$ (Jassby et al. 2002).

\section{Data Collection}

\section{Sampling}

Data included in this study were collected at discrete sampling sites ranging from Suisun Bay to the upstream central Delta (Fig. 1) during high slack tide by the California Department of Fish and Game as part of the Interagency Ecological Program for the San Francisco Estuary (IEP). Samples were collected twice monthly from April to October and monthly in March and November between 1972 and 1993, and afterwards at a monthly interval year-round. Sampling stations are in tidal river habitat channels (and a few tidal marsh slough sites) that are well mixed with depths between about 3 and $15 \mathrm{~m}$.

\section{Water Quality Variables}

Temperature and electrical conductivity were measured at every sampling event. Surface electrical conductivity was converted to salinity using the Practical Salinity Scale 1978 in the range of 2-42 (Fofonoff and Millard 1983) and the extension by Hill et al. (1986) for salinities below 2. Starting in 1976, chlorophyll $a(\mathrm{Chl}-a)$ was measured from water samples collected at a depth of $1 \mathrm{~m}$ at each sampling station. Chl- $a$ concentration was determined by spectrophotometric analysis after acetone extraction of particles collected onto Gelman Type A/E glass fiber filters. Historical mean daily flow rates for the upper SF Estuary are obtained with Dayflow, a software accounting package to estimate historical hydrology
(IEP 2006). In the present study, we included estimated total inflow (the sum of all observed river and floodplain flows to the Delta), exports (the sum of all exports and diversions/ transfers), and outflow (after correcting total inflow for exports, net precipitation, and within-Delta water diversions).

\section{Zooplankton}

Large-sized zooplankton were collected using a ClarkeBumpus net (154- $\mu \mathrm{m}$ mesh size) and smaller-sized organisms including rotifers, Limnoithona spp., Oithona spp., harpacticoids, and nauplii from pumped water through a $64-\mu \mathrm{m}$ mesh with a pump of $15-\mathrm{Lmin}^{-1}$ capacity. Pumped water was collected in a carboy and approximately $1.7 \mathrm{~L}$ sampled for analysis. Mysid species were collected with a conical net of 505- $\mu \mathrm{m}$ mesh size. Zooplankton were sampled from bottom-to-surface using oblique 10-min net tows or pumped water from discrete water depths (bottom, midwater, surface). At least 200 organisms were counted per sample (for details, see Orsi and Mecum 1986), and organisms were identified to species or genus level (taxonomic categories are listed in the Electronic Supplementary Material (ESM) Table S1). Copepods were classified to adult and copepodite life stages, abundant calanoid nauplii were identified to species, and the remaining were lumped together in a separate group. Micro- and mesozooplankton densities were converted to dry weight from literature-derived weight-length regressions (Dumont et al. 1975; Lonsdale and Coull 1977; Durbin and Durbin 1978; Pauli 1989; Kimmerer 2006; Almeda et al. 2010) or direct measurements of dry weight and assuming a carbon-to-dry weight ratio of $42 \%$ for copepods and $45 \%$ for the remaining taxa. Mysid size was measured for 100 (or maximum available if <100) randomly picked individuals per sampling date and dry weight estimated from length-weight regression equations obtained for Neomysis mercedis and Acanthomysis bowmani (unpublished results from J. Orsi, California Department of Fish and Game, Stockton). For the remaining species, the length-weight relation of $N$. mercedis was used. A carbon-to-dry weight ratio of $40 \%$ was assumed to estimate mysid biomass (Uye 1982).

\section{Data Analysis}

In the present study, we confine the analysis to 13 stations that have been sampled continuously over the sampling period between 1972 and 2008, except stations M10 and S42, which started in 1974 (Fig. 1). The stations were divided into two almost equal groups based on their distance along the upstream-downstream axis of the estuary (station 74 was assigned to the downstream group). These groupings also correspond closely to two subregions that can be identified 
Fig. 1 Map of the upper San Francisco Estuary consisting of Suisun Bay and the Sacramento-San Joaquin Delta. Zooplankton sampling stations included in the present study and the two subregions (suisun, delta) are highlighted. Suisun sampling stations include $S 42$, $32,28,48,54,60$, and 74 ; delta stations $64, D 16,86$, D28, M10, and 92

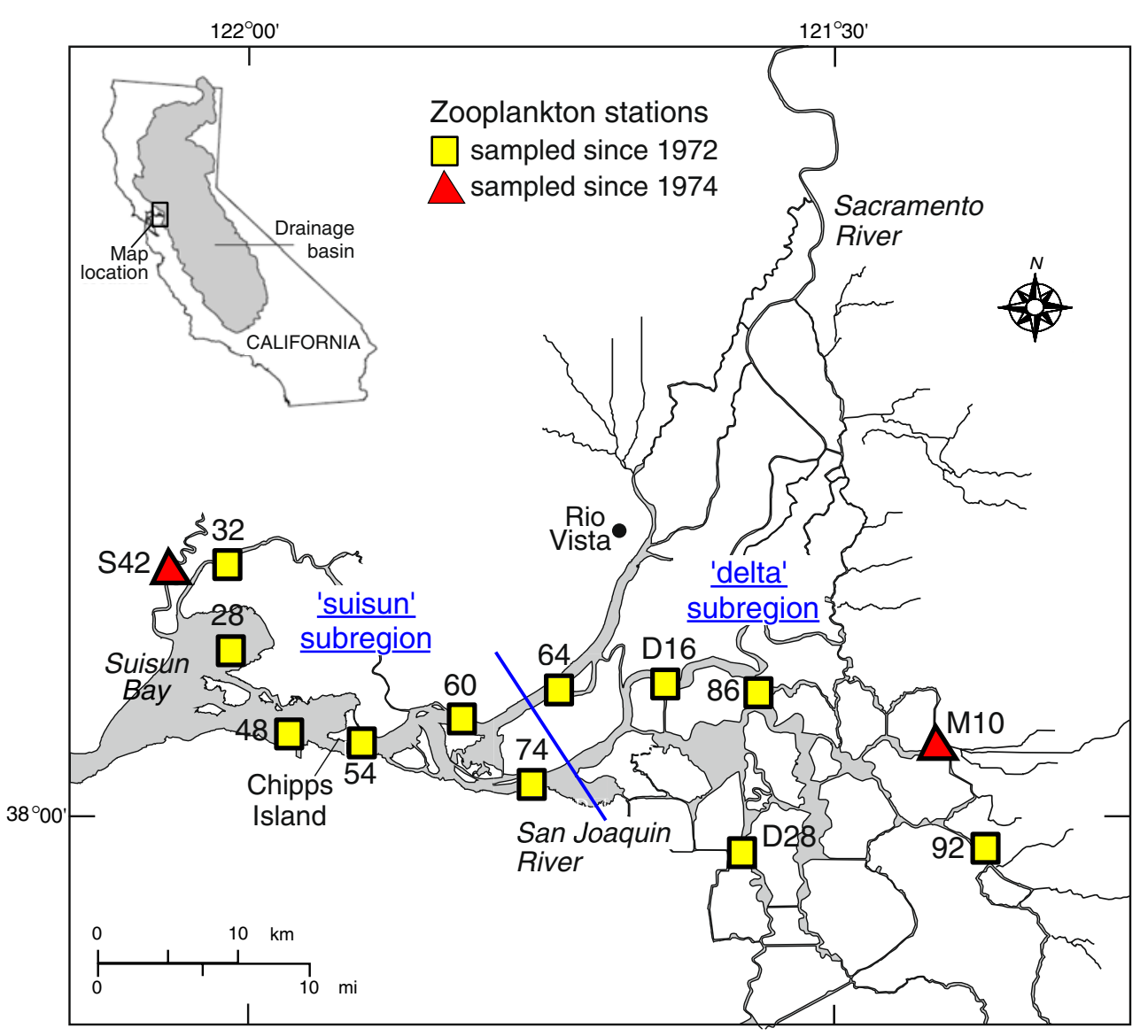

by (rotated) principal component analysis of the abundances of L. tetraspina, the dominant species that started proliferating in the estuary in 1993 (the methods are as described by Jassby et al. 2002). ESM Figure S1 shows the component coefficients for the two rotated principal components and, in particular, the consistency with the station groupings. Only station 64 has an ambiguous affiliation, and we kept it with the upstream group to balance the data set as much as possible. Data from the stations in each subregion were averaged for a regional representation of the data. Because the division occurs near the confluence of the Sacramento and San Joaquin rivers and the boundary between the Delta and Suisun Bay, we refer to the downstream as the "suisun subregion" and the upstream as the "delta subregion" (Fig. 1).

The food web of the estuary experienced major shifts over the course of the sampling period. Especially, abrupt food web changes related to the invasion of the clam $C$. amurensis and several zooplankters occurred between 1987 and 1994 (Orsi and Ohtsuka 1999; Kimmerer 2002) and correspond to an extended drought period. Therefore, we sometimes choose to contrast values for the period 19721986 and 1995-2008 to highlight differences between the earlier and later portions of the sampling program and correspond to the years before (pre-drought) and after (postdrought) the extended drought. The latter period was further separated into two time periods that correspond approximately with the abrupt decline of several pelagic fishes in 2002 (Sommer et al. 2007; Thomson et al. 2010).

Annual averages were calculated from March through November and trend statistics calculated by aggregating stations within a region (see Fig. 1) by their mean for each station and month. The long-term trend estimate for each variable was then calculated as the linear slope and statistical significance of the slope was determined using the seasonal Kendall (for monthly data) or Mann-Kendall (for annualized data) test (Helsel and Hirsch 1992). Slopes were expressed as percent per year by dividing by the long-term mean of the variable. To avoid type I error, a threshold $p$ value of 0.005 was considered to help compensate for serial correlation among months or among years in the time series. Calculations and tests were carried out in the $\mathrm{R}$ software environment 2.10.0 (R Development Core Team 2009).

\section{Results}

Long-Term Trends in Water Quality

Characteristic of the Mediterranean climate, inflows to the Delta are highly seasonal and peak during the winter 
months (Fig. 2). Water outflow from the Delta reflects water inflow to the Delta, neither of which shows a longterm trend throughout the zooplankton sampling program $(p>0.3)$. However, river inflow and outflow do exhibit high interannual variability, ranging from annual average inflows of 226 up to $2930 \mathrm{~m}^{3} \mathrm{~s}^{-1}$ during the dry and wet El-NiñoSouthern Oscillation years of 1977 and 1983, respectively. An extended drought period occurred during 1987-1994 with low water inflow and outflow (averaging 490 and $268 \mathrm{~m}^{3} \mathrm{~s}^{-1}$ for inflow and outflow, respectively). Export rates increased significantly at $1 \%$ year $^{-1} \quad(p<0.001)$ between 1972 and 2008.

Water salinity varies widely within the system, ranging from limnetic to sporadic oligohaline conditions in the upstream delta to mesohaline conditions in the downstream suisun subregion (Fig. 3). In the upstream delta subregion, annual averaged salinity was $0.33 \pm 0.04$ (SE) over the sampling period and in suisun $4.4 \pm 0.43$. Salinity varied greatly among years and seasons, reflecting freshwater inflow to the Delta, and was generally low in spring and increased in summer and fall (Fig. 3). High interannual salinity fluctuations were observed especially in the downstream suisun subregion, ranging from 0.2 to 11.6. Salinity was elevated during the dry water years from 1987 to 1994 (Fig. 3). On an annual basis, salinity exhibited only a weak positive trend in suisun and no trend in the delta during 1972-2008 (Table 1). But salinity did increase significantly in both subregions during 1995-2008 (Table 1).

Chl- $a$ concentration dropped significantly in both subregions in the mid-1980s and has remained at a relatively low level since then, particularly in suisun (Fig. 4). Regional declining trends ranged from $-2.7 \%$ to $-6.2 \%$ per year (Table 1) and were strongest in suisun over the entire sampling period. Chl- $a$ increased in the delta subregion after 1996, but concentrations were still below values prior to 1986 . Before 1986, annual average Chl- $a$ concentrations for the two subregions ranged from 3.6 to $10.4 \mu \mathrm{g} \mathrm{L}^{-1}$, with highest values in the suisun subregion.
Since 1995, annual averages ranged from 2.7 to $4.3 \mu \mathrm{g} \mathrm{L}{ }^{-1}$, with highest values in the delta subregion (Table 2).

Long-Term Trends in Zooplankton

\section{Contribution of Major Taxa to Zooplankton Biomass}

The zooplankton community showed major changes over the course of the sampling period, in species composition and total abundance (Figs. 5, 6, 7, and 8). Total zooplankton biomass showed high interannual variability and significant declining trends within both regions (Table 1). In suisun, total zooplankton biomass declined between 1972 and 1994 from about 30 to $10 \mu \mathrm{g} \mathrm{C} \mathrm{L}^{-1}$ and recovered thereafter to about $20 \mu \mathrm{g} \mathrm{C} \mathrm{L}{ }^{-1}$; in the delta subregion, zooplankton biomass dropped from approximately $60 \mu \mathrm{g} \mathrm{C} \mathrm{L}^{-1}$ in the 1970 s to $20 \mu \mathrm{g} \mathrm{C} \mathrm{L}^{-1}$ after the early 1980s (Fig. 5a).

Rotifers showed a declining trend in both subregions (Table 1) and decreased from an annual average of approximately 10 and $15 \mu \mathrm{g} \mathrm{C} \mathrm{L} \mathrm{L}^{-1}$ in the 1970 s to 1 and $4 \mu \mathrm{g} \mathrm{C} \mathrm{L}^{-1}$ after 1990 , or between $-7.4 \%$ and $-6.1 \%$ per year, respectively. Similarly, cladocerans declined significantly in both subregions: from 27 to $6 \mu \mathrm{g} \mathrm{C} \mathrm{L}^{-1}$ in the delta and from 1.2 to $0.2 \mu \mathrm{g} \mathrm{C} \mathrm{L}^{-1}$ in suisun. Calanoids declined in suisun from 14 to $4 \mu \mathrm{g} \mathrm{C} \mathrm{L}^{-1}$, but increased in the delta subregion from 4 to $8 \mu \mathrm{g} \mathrm{C} \mathrm{L}^{-1}$ in the 1970 s and after 1990. In addition, cyclopoids showed a significant increasing trend in the downstream suisun subregion from $0.4 \mu \mathrm{g} \mathrm{C} \mathrm{L}^{-1}$ in the 1970 s to $4 \mu \mathrm{g} \mathrm{C} \mathrm{L}^{-1}$ after 1990 . In contrast, cyclopoids declined in the delta from an annual average in the 1970s of 4 to $1 \mu \mathrm{g} \mathrm{C} \mathrm{L}^{-1}$ after 1990 and nauplii from 2.9 to $1.7 \mu \mathrm{g} \mathrm{C} \mathrm{L}^{-1}$ (Fig. 5a and Table 1).

The contribution of rotifers to total micro- and mesozooplankton biomass declined considerably in both subregions over the sampling period. Whereas rotifers contributed more than $25 \%$ prior to 1987 , they made up $<7 \%$ of zooplankton biomass after 1994 in suisun (Fig. 5 and Table 2). In the delta,
Fig. 2 Historical flow rate variables for the San Francisco Estuary between 1972 and 2008: Freshwater inflow is mainly from the Sacramento and San Joaquin rivers and the Yolo Bypass flow addition near Rio Vista, outflow is net Delta outflow past Chipps Island, and exports is water diverted from the Delta to state and federal water projects. See Fig. 1 for site location

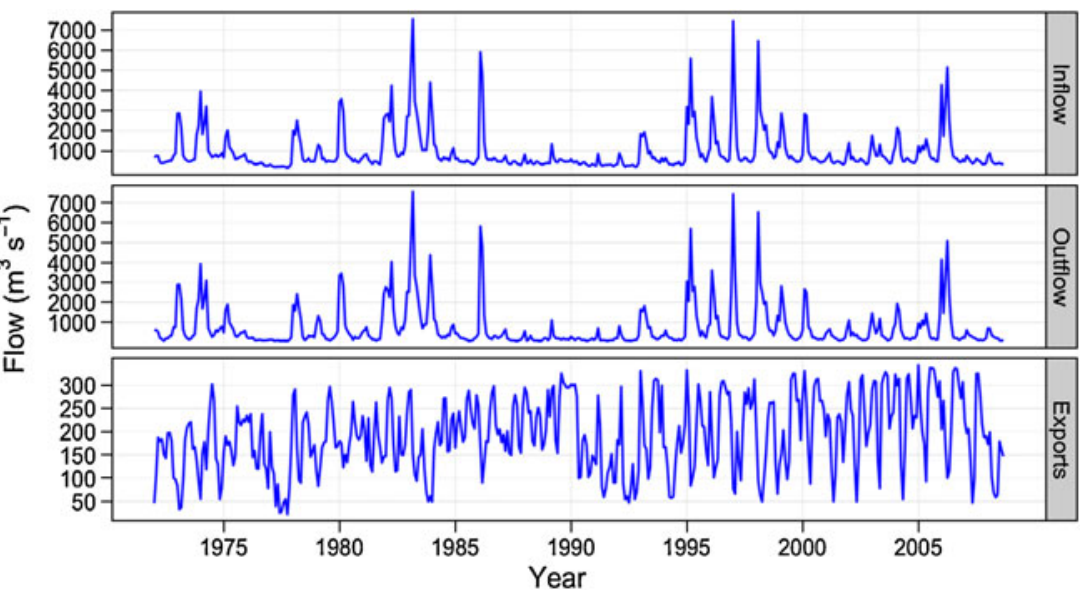


Fig. 3 Annual average salinity by season (spring, summer, fall) and subregion (see Fig. 1) in the upper San Francisco Estuary between 1972 and 2008. Top panels represent the "suisun" and bottom panels the "delta" subregion. Blue line displays a loess fit \pm standard error (shaded area)

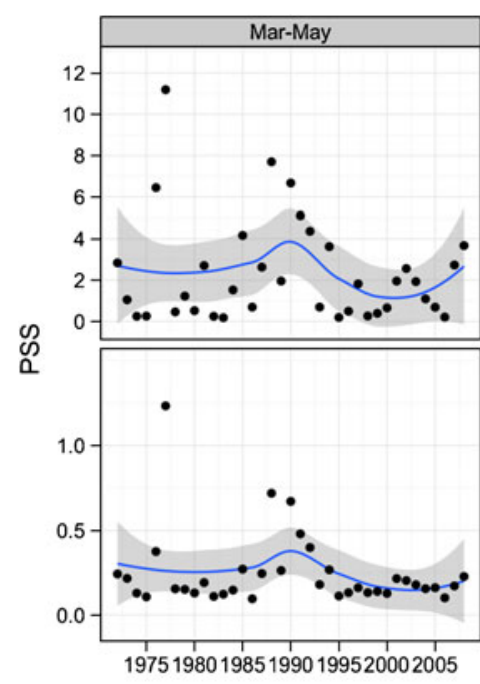

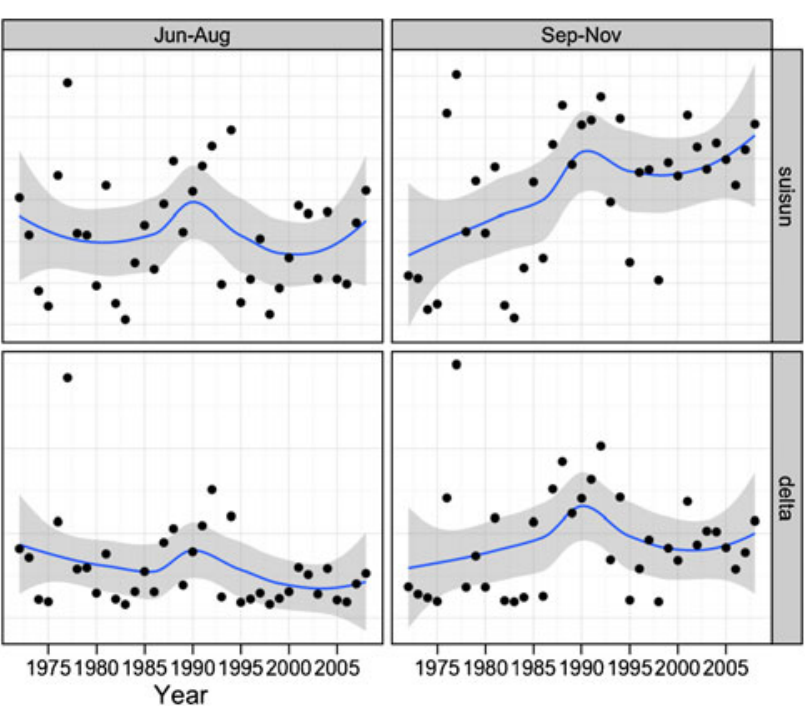

the rotifer contribution declined from $25 \%$ to $18 \%$. Cladocerans showed similar strong declines, particularly in the upstream subregion (Table 2); at the upper estuary-wide scale, their contribution declined almost twofold. In addition, the proportion of micro- and mesozooplankton biomass accounted for by calanoids decreased by about half in suisun in recent years compared to the years before 1987. However, this taxonomic group showed a regional increase in the delta from $12 \%$ to $37 \%$ of micro- and mesozooplankton biomass. The regional decline of rotifers, cladocerans, and calanoids was counterbalanced by an increase in cyclopoids in suisun. In this subregion, cyclopoids comprised $<2 \%$ of zooplankton biomass before 1987 but contributed more than $24 \%$ after 1994 , and the proportion of nauplii increased from $<18 \%$ to more than $28 \%$ over the same time period (Fig. 5 and Table 2). Even though species of this ontogenetic life stage were only identified for abundant calanoid species, it can be assumed that the majority of nauplii were L. tetraspina species as this species dominated copepod abundance after 1994 and calanoids decreased in this subregion.

\section{Long-Term Trends of Zooplankton Species Composition}

The dominant copepod species were essentially replaced by newly introduced species over the 37-year study period. Trend statistics of zooplankton species biomass are shown in Table 3. During the period 1972-1986, calanoid biomass was mainly dominated by Eurytemora spp., Acartia spp., and Diaptomidae species, reaching highest values in suisun with annual average biomass up to $4.9,1.9$, and $3.4 \mu \mathrm{g} \mathrm{C} \mathrm{L}^{-1}$ and densities of 1,632, 619, and 3,296 individuals per cubic meter, respectively (Fig. 6). During this

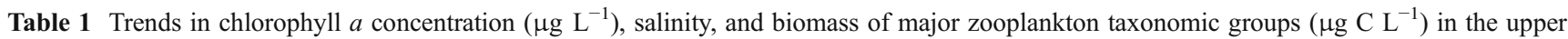
San Francisco Estuary by subregion (see Fig. 1) for the periods 1972-2008 and 1995-2008

\begin{tabular}{|c|c|c|c|c|c|c|c|c|}
\hline \multirow[t]{2}{*}{ Variables } & \multicolumn{2}{|c|}{ “Suisun” (1972-2008) } & \multicolumn{2}{|c|}{ “Suisun” (1995-2008) } & \multicolumn{2}{|c|}{ "Delta" (1972-2008) } & \multicolumn{2}{|c|}{ “Delta" (1995-2008) } \\
\hline & $\begin{array}{l}\text { Trends } \\
\text { (\%per year) }\end{array}$ & $p$ & $\begin{array}{l}\text { Trends } \\
\text { (\%per year) }\end{array}$ & $p$ & $\begin{array}{l}\text { Trends } \\
\text { (\%per year) }\end{array}$ & $p$ & $\begin{array}{l}\text { Trends } \\
\text { (\%per year) }\end{array}$ & $p$ \\
\hline Chlorophyll $a$ & -6.2 & $<0.001$ & 1.6 & 0.16 & -2.7 & $<0.001$ & 1.3 & 0.40 \\
\hline Salinity & 0.6 & 0.02 & 5.6 & $<0.001$ & -0.8 & 0.71 & 4.3 & $<0.001$ \\
\hline Rotifera & -7.4 & $<0.001$ & 0.0 & 0.10 & -6.1 & $<0.001$ & 1.7 & 0.40 \\
\hline Cladocera & -7.2 & $<0.001$ & -10.0 & 0.07 & -5.5 & $<0.001$ & 8.7 & 0.01 \\
\hline Calanoida & -4.6 & $<0.001$ & -3.2 & 0.02 & 2.5 & $<0.001$ & 1.9 & 0.20 \\
\hline Cyclopoida & 8.6 & $<0.001$ & 6.8 & $<0.001$ & -5.1 & $<0.001$ & 3.2 & 0.34 \\
\hline Harpacticoida & -0.2 & 0.71 & -5.6 & 0.01 & 1.4 & 0.77 & -11.5 & 0.10 \\
\hline Nauplii & 0.4 & 0.61 & 6.8 & $<0.001$ & -2.1 & $<0.001$ & 4.2 & $<0.001$ \\
\hline $\begin{array}{l}\text { Total zooplankton } \\
\text { (excluding mysids) }\end{array}$ & -2.3 & $<0.001$ & 1.9 & $<0.001$ & -3.4 & $<0.001$ & 2.9 & 0.18 \\
\hline Mysids & -8.1 & $<0.001$ & 0.9 & 0.10 & -7.8 & $<0.001$ & -4.1 & 0.19 \\
\hline
\end{tabular}

Trends are shown as percent change per year; significant trends $(p<0.005$ for this study) are shown in italics 


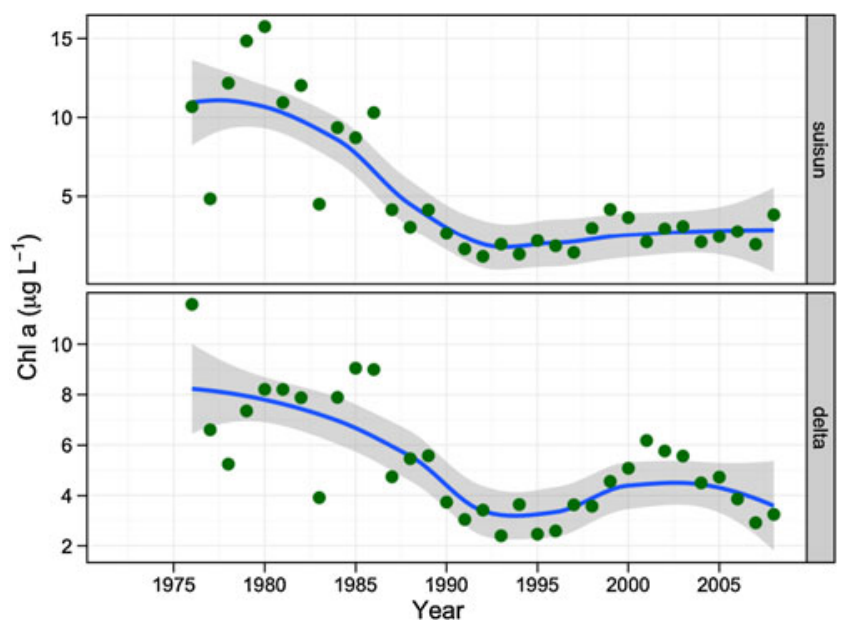

Fig. 4 Annual average chlorophyll $a$ concentration by subregion (see Fig. 1) in the upper San Francisco Estuary between 1976 and 2008. Top panel represents the "suisun" and bottom panel the "delta" subregion. The blue line displays a loess fit \pm standard error (shaded area)

time period, Sinocalanus spp. also reached relatively high values after its introduction in 1978 , up to $1.8 \mu \mathrm{g} \mathrm{C} \mathrm{L} \mathrm{L}^{-1}$ biomass and densities of 602 individuals per cubic meter in the delta subregion. In contrast, during 1995-2008, biomass of these species dropped below $0.9 \mu \mathrm{g} \mathrm{C} \mathrm{L^{-1 }}$ in both subregions, and the introduced Pseudodiaptomus forbesi and Acartiella spp. dominated the calanoid community throughout the upper SF Estuary (Fig. 6), reaching highest values in the delta subregion with average abundances of 5,888 individuals per cubic meter and biomass of $6.9 \mu \mathrm{g} \mathrm{C} \mathrm{L}^{-1}$. Acartiella spp. was more abundant in the downstream subregion, reaching values up to 491 individuals per cubic meter and biomass of $0.7 \mu \mathrm{g} \mathrm{C} \mathrm{L}^{-1}$. In addition, Tortanus spp. appeared in suisun in 1993 and displayed abundances of 103 individuals per cubic meter and biomass of $0.2 \mu \mathrm{g} \mathrm{C} \mathrm{L} \mathrm{L}^{-1}$, but appeared only sporadically in the upstream delta subregion.

Cyclopoids experienced not only a shift in species composition but also a significant increase in abundance and biomass in suisun (Fig. 6). The increasing trend is a result of the success of $L$. tetraspina since its introduction in 1993 (Orsi and Ohtsuka 1999). This cyclopoid reached annual-averaged densities of up to 57,900 individuals per cubic meter in suisun (Fig. 6), outnumbering copepod densities observed in the upper estuary throughout the last decades. However, due to its small size (length $0.5 \mathrm{~mm}$ ), biomass of this species was on average only about $4.2 \mu \mathrm{g} \mathrm{C} \mathrm{L}^{-1}$. This species and its congener L. sinensis reached moderate densities of about 8,056 individuals per cubic meter and biomass of $0.5 \mu \mathrm{g} \mathrm{C} \mathrm{L}^{-1}$ in the upstream delta subregion. To a lesser extent, the increase in cyclopoids was also due to Oithona davisae in the downstream subregion (Table 3) where it reached abundances of up to 870 individuals per cubic meter and biomass of $0.02 \mu \mathrm{g} \mathrm{C} \mathrm{L}^{-1}$. Coincident with the increase in cyclopoids, the ratio of nauplii to adult copepod abundance was lowered to $5 \pm 0.7$ (SD) compared to the historical ratio of $11 \pm 4$ in suisun. This ratio also declined at about the same rate in the upstream delta subregion in the late 1980s, synchronous with the increase of Pseudodiaptomus spp. and clam (C. amurensis) expansion.

Cladocerans dominated in the upstream limnetic part of the estuary and appeared only sporadically in the downstream subregion (Fig. 7). Bosmina spp. and Daphnia spp. were the dominant representatives of this group: Bosmina spp. annual-averaged abundances and biomass were

Table 2 Chlorophyll $a$ concentration $\left(\mu \mathrm{g} \mathrm{L}^{-1}\right)$ and biomass $\left(\mu \mathrm{g} \mathrm{C} \mathrm{L}^{-1}\right)$ of major zooplankton taxonomic groups ( \pm standard error) in the upper San Francisco Estuary by subregion (see Fig. 1) for the periods 1972-1986, 1995-2001, and 2002-2008, respectively

\begin{tabular}{|c|c|c|c|c|c|c|}
\hline \multirow[t]{2}{*}{ Variable } & \multicolumn{3}{|l|}{ "Suisun" } & \multicolumn{3}{|l|}{ "Delta" } \\
\hline & $1972-1986$ & $1995-2001$ & 2002-2008 & 1972-1986 & 1995-2001 & 2002-2008 \\
\hline Chlorophyll $a$ & $10.4 \pm 1.1$ & $2.6 \pm 0.4$ & $2.7 \pm 0.2$ & $7.7 \pm 0.6$ & $4.0 \pm 0.5$ & $4.4 \pm 0.4$ \\
\hline Rotifera & $7.8 \pm 1.3$ & $1.3 \pm 0.3$ & $1.2 \pm 0.4$ & $11.1 \pm 2.6$ & $3.1 \pm 0.3$ & $4.5 \pm 0.7$ \\
\hline Cladocera & $1.1 \pm 0.4$ & $0.2 \pm 0.1$ & $0.1 \pm 0.0$ & $20.1 \pm 3.1$ & $3.4 \pm 0.5$ & $7.8 \pm 1.7$ \\
\hline Calanoida & $11.4 \pm 1.3$ & $4.6 \pm 0.6$ & $3.8 \pm 0.4$ & $4.0 \pm 0.6$ & $6.9 \pm 0.6$ & $8.3 \pm 0.8$ \\
\hline Cyclopoida & $0.4 \pm 0.1$ & $3.6 \pm 0.6$ & $5.7 \pm 0.5$ & $2.7 \pm 0.8$ & $1.0 \pm 0.2$ & $1.3 \pm 0.2$ \\
\hline Harpacticoida & $3.0 \pm 0.4$ & $3.6 \pm 0.6$ & $2.4 \pm 0.2$ & $0.8 \pm 0.1$ & $2.4 \pm 0.8$ & $0.6 \pm 0.1$ \\
\hline Nauplii & $4.9 \pm 0.5$ & $4.0 \pm 1.5$ & $6.5 \pm 1.2$ & $2.9 \pm 0.3$ & $1.4 \pm 0.2$ & $1.9 \pm 0.3$ \\
\hline Total zooplankton excluding mysids & $28.6 \pm 2.3$ & $17.4 \pm 1.4$ & $19.6 \pm 1.2$ & $41.5 \pm 5.8$ & $18.3 \pm 1.5$ & $24.4 \pm 2.8$ \\
\hline Mysids & $18.1 \pm 2.5$ & $1.2 \pm 0.3$ & $0.5 \pm 0.2$ & $5.6 \pm 1.0$ & $0.6 \pm 0.2$ & $0.2 \pm 0.1$ \\
\hline
\end{tabular}

This division allows contrasting the first (1972-1986) and second (1995-2008) parts of the sampling period, excluding transition years of the 1987-1994 drought as well as equal-length periods before (1995-2001) and after (2002-2008) the abrupt decline of several pelagic fishes in the early 2000 s 


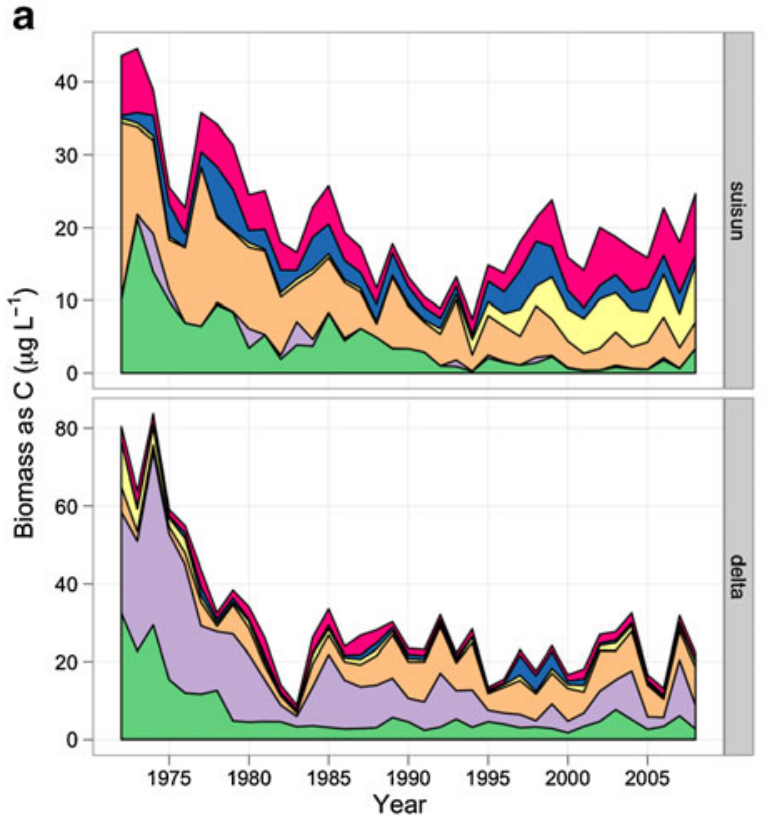

Fig. 5 Annual average zooplankton biomass (excluding mysids) by subregion (see Fig. 1) in the upper San Francisco Estuary between 1972 and 2008. a Annual averages of major taxonomic groups by

5,709 individuals per cubic meter and $8.6 \mu \mathrm{g} \mathrm{C} \mathrm{L} \mathrm{L}^{-1}$ from 1972 to 1986 and Daphnia spp. 1,245 individuals per cubic meter and $10 \mu \mathrm{g} \mathrm{C} \mathrm{L}^{-1}$, respectively (Fig. 7; see ESM Fig. S2A for densities). Both taxa experienced a significant

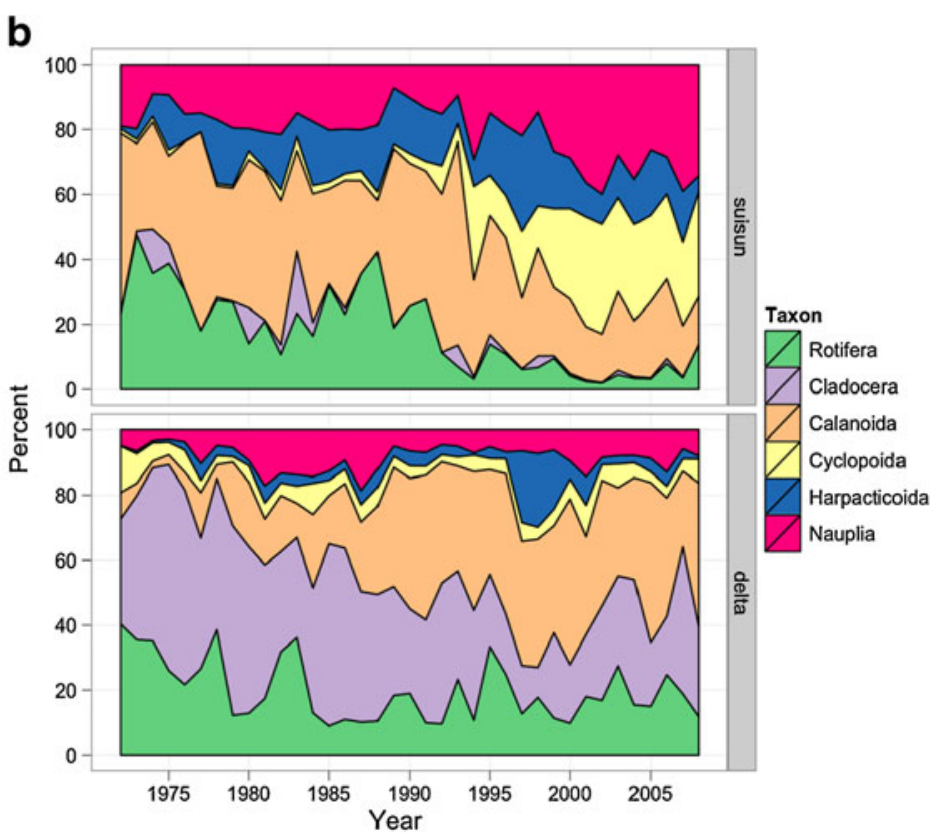

region. b Percentage of major taxonomic groups by suregion. Top panels represent the "suisun" and bottom panels the "delta" subregion

decline on the order of about $-6 \%$ per year (Table 3 ). After 1994, values dropped to 1,222 individuals per cubic meter and $1.8 \mu \mathrm{g} \mathrm{C} \mathrm{L}^{-1}$ for Bosmina spp. and to 300 individuals per cubic meter and $2.4 \mu \mathrm{g} \mathrm{C} \mathrm{L}^{-1}$ for Daphnia spp. a

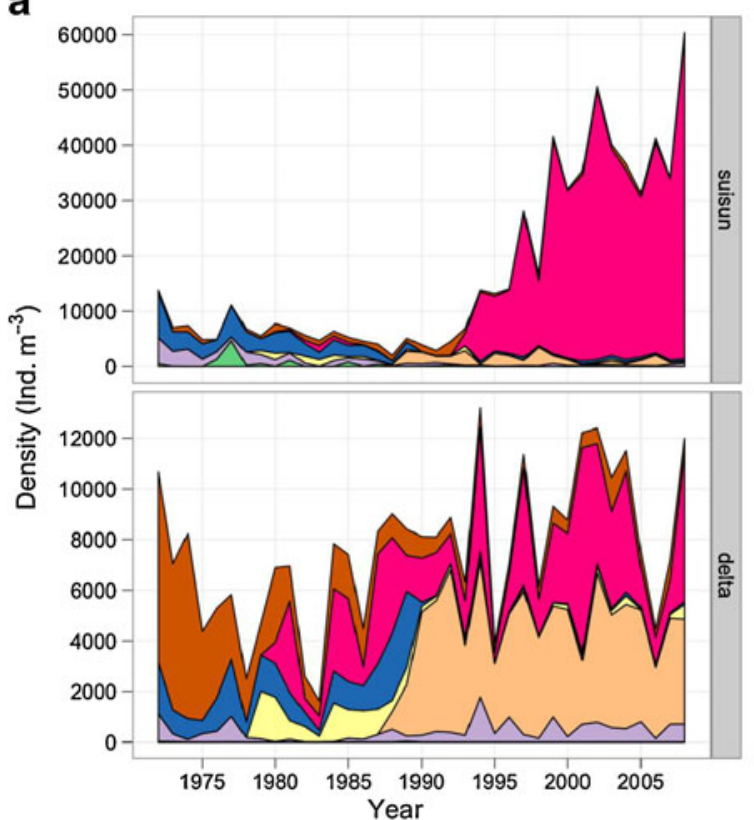

b

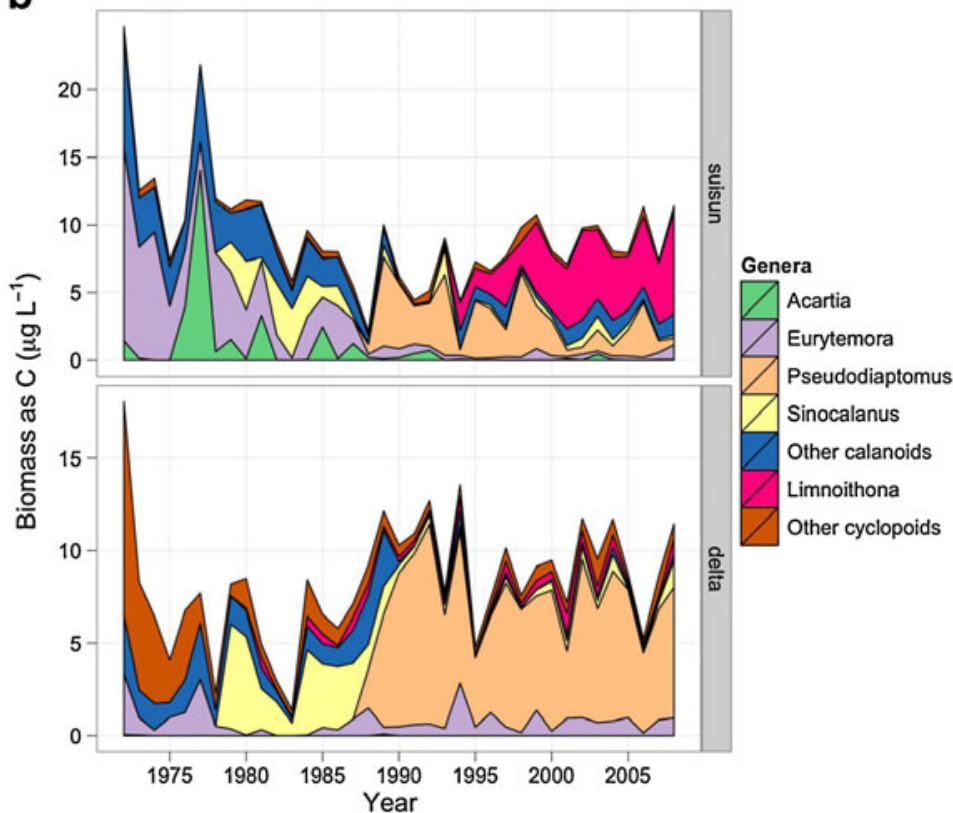

Fig. 6 Annual averaged abundances (a) and biomass (b) of copepod species by subregion (see Fig. 1) in the upper San Francisco Estuary between 1972 and 2008. Other calanoids include Acartiella spp., Tortanus spp., immature Diaptomidae, and unidentified calanoid species; other cyclopoids include Oithona davisae, Acanthocyclops vernalis, and unidentified cyclopoid species. The genus Limnoithona was dominated by L. tetraspina. Top panels represent the "suisun" and bottom panels the "delta" subregion 


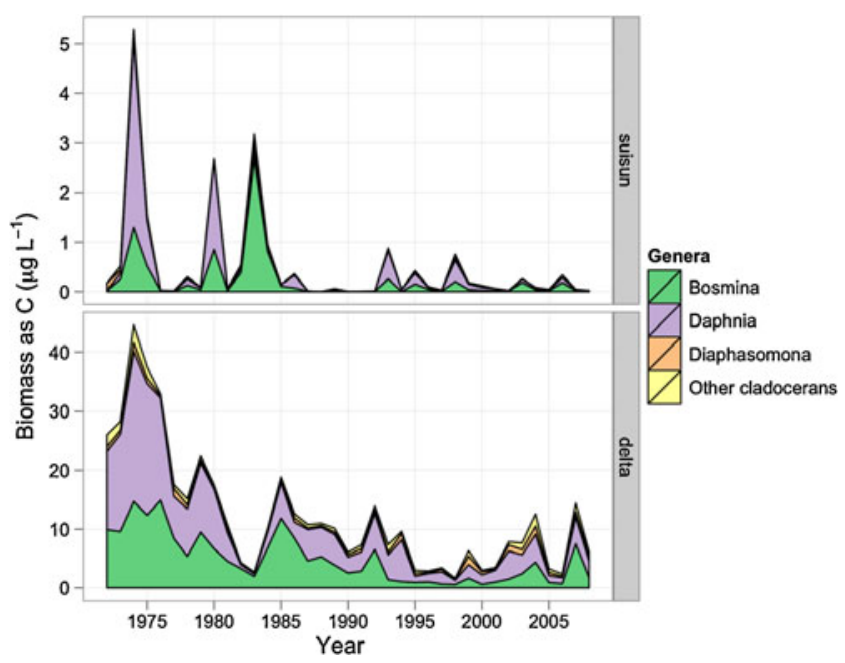

Fig. 7 Annual average biomass of cladoceran species by subregion (see Fig. 1) in the upper San Francisco Estuary between 1972 and 2008. Other Cladocera include unidentified cladocerans. Top panel represents the "suisun" and bottom panel the "delta" subregion

Keratella spp. and Polyarthra spp. dominated the rotifer community in the freshwater delta subregion, whereas Synchaeta spp. dominated in the higher salinity region of suisun (Fig. 8; see ESM Fig. S2B for densities). Keratella spp. and Polyarthra spp. reached averaged abundances of 15,000 individuals per cubic meter and biomass of $2.4 \mu \mathrm{g} \mathrm{C} \mathrm{L} \mathrm{L}^{-1}$ in the delta subregion. Polyarthra spp. was the only rotifer species that did not exhibit a significant declining trend over the sampling period (Table 3). In contrast, Synchaeta spp. showed a strong decline throughout the upper SF Estuary at a rate of $-6.0 \%$ to $-4.9 \%$ per year (Table 3). Their strongest decline was observed in suisun where abundances dropped to approximately $20 \%$ after 1994 compared to the time period 1972-1986 when they reached values up to 44,000 individuals per cubic meter and biomass of $2.9 \mu \mathrm{g} \mathrm{C} \mathrm{L} \mathrm{L}^{-1}$ (Fig. 8).

Major changes occurred also within the mysid community at the end of 1980. Mysid biomass was in general highest in the higher salinity subregion of suisun compared to the upstream delta. Overall biomass declined rapidly throughout the upper SF Estuary between the periods 1972-1986 and 1995-2008, from regional annual averages of approximately 96 individuals per cubic meter or $18 \mu \mathrm{g} \mathrm{C} \mathrm{L}^{-1}$ to values below 16 individuals per cubic meter or $1.1 \mu \mathrm{g} \mathrm{C} \mathrm{L}^{-1}$ in suisun and from 5.5 to $0.4 \mu \mathrm{g} \mathrm{C} \mathrm{L}^{-1}$ in the delta (Fig. 9; see ESM Fig. $\mathrm{S} 2 \mathrm{C}$ for densities). In addition to the strong decline in mysid biomass, species composition changed in the early 1990s. The native $N$. mercedis was replaced largely by the introduced species Hyperacanthomysis longirostris, which dominated the community thereafter. Overall, $N$. mercedis declined at a rate of about $-9 \%$ per year and $H$. longirostris increased at about the same rate (Table 3). Other introduced mysid species remained relatively scarce (Fig. 9).

\section{Zooplankton Size}

The shift in zooplankton species dominance resulted in significant size changes throughout the upper SF Estuary (Fig. 10). In suisun, average micro- and mesozooplankton size declined in the late 1990 s from about 0.27 to $0.17 \mu \mathrm{g}$ in most recent years $(p<0.001)$. This declining trend coincided with the increasing dominance of $L$. tetraspina in the early 1990s in this region (Figs. 5 and 6 and Table 3). In contrast, average size increased in the upstream region from approximately 0.2 to $0.4 \mu \mathrm{g}(p<0.001)$, which is likely due to the replacement of rotifers and cladocerans with larger-sized Pseudodiaptomus species. In addition, average mysid size showed an abrupt drop from an average of $5.8 \mathrm{~mm}$ in the $1970 \mathrm{~s}$ and $1980 \mathrm{~s}$ to about $4.4 \mathrm{~mm}$ since 2000 throughout the upper SF Estuary (Fig. 10). This change occurred in the upstream delta subregion around 1990 and in suisun in the mid 1990s.

\section{Discussion}

Long-Term and Abrupt Changes in Zooplankton Biomass and Species Composition

The present study showed large spatial and temporal changes of the zooplankton community in the Sacramento-San Joaquin Delta and Suisun Bay over the last four decades in both abundances and species composition. Major shifts in the zooplankton community composition coincided with the extended drought during 1987-1994 and explosive colonization of the invasive clam $C$. amurensis at the beginning of the drought (Carlton et al. 1990; Alpine and Cloern 1992). The

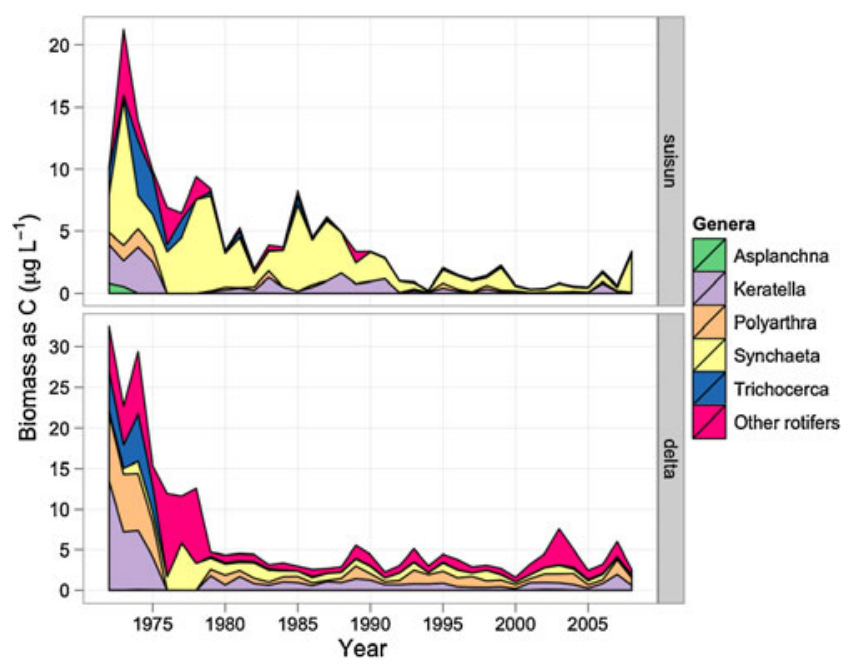

Fig. 8 Annual average biomass of rotifer species by subregion (see Fig. 1) in the upper San Francisco Estuary between 1972 and 2008. Other Rotifera include unidentified rotifers. Top panel represents the "suisun" and bottom panel the "delta" subregion 
Table 3 Trend statistics of zooplankton species biomass ( $\mu \mathrm{g} \mathrm{C} \mathrm{L}^{-1}$ ) in the upper San Francisco Estuary by subregions between 1972 and 2008
Trends are shown as percent change per year; significant trends $(p<0.005$ for this study) are shown in italics

${ }^{\text {a }}$ Formerly Acanthomysis bowmani

\begin{tabular}{|c|c|c|c|c|}
\hline \multirow[t]{2}{*}{ Taxon } & \multicolumn{2}{|l|}{ "Suisun" } & \multicolumn{2}{|l|}{ "Delta" } \\
\hline & Trend (\% per year) & $p$ & Trend (\% per year) & $p$ \\
\hline \multicolumn{5}{|l|}{ Copepoda } \\
\hline Acartia spp. & -9.04 & $<0.001$ & -8.55 & 0.57 \\
\hline Acartiella spp & 10.44 & $<0.001$ & 9.72 & $<0.001$ \\
\hline Eurytemora spp. & -9.50 & $<0.001$ & -1.18 & 0.71 \\
\hline Pseudodiaptomus spp. & 5.27 & $<0.001$ & 6.94 & $<0.001$ \\
\hline Sinocalanus spp. & -2.55 & 0.01 & -3.05 & 0.30 \\
\hline Tortanus spp. & 10.35 & $<0.001$ & 8.53 & $<0.001$ \\
\hline Other calanoids & -9.49 & $<0.001$ & -8.05 & $<0.001$ \\
\hline Limnoithona spp. & 10.70 & $<0.001$ & 4.75 & $<0.001$ \\
\hline Oithona davisae & 2.81 & $<0.001$ & 6.76 & - \\
\hline Other cyclopoids & -1.12 & 0.004 & -7.44 & $<0.001$ \\
\hline \multicolumn{5}{|l|}{ Cladocera } \\
\hline Bosmina spp. & -6.30 & $<0.001$ & -5.72 & $<0.001$ \\
\hline Daphnia spp. & -8.27 & 0.123 & -6.26 & $<0.001$ \\
\hline Diaphasomona spp. & -9.25 & - & 0.70 & 0.523 \\
\hline Other cladocerans & -2.70 & 0.262 & -1.87 & 0.904 \\
\hline \multicolumn{5}{|l|}{ Rotifera } \\
\hline Asplanchna spp. & -15.16 & $<0.001$ & -0.4617 & $<0.001$ \\
\hline Keratella spp. & -7.24 & $<0.001$ & -7.3997 & $<0.001$ \\
\hline Synchaeta spp. & -6.09 & $<0.001$ & -3.8733 & $<0.001$ \\
\hline Trichocerca spp. & -12.12 & $<0.001$ & -12.248 & $<0.001$ \\
\hline Polyarthra spp. & -8.23 & 0.19 & -5.4223 & 0.47 \\
\hline Other rotifers & -9.65 & $<0.001$ & -5.2815 & $<0.001$ \\
\hline \multicolumn{5}{|l|}{ Mysids } \\
\hline Acanthomysis aspera & 7.61 & 0.154 & - & - \\
\hline Hyperacanthomysis longirost ${ }^{\text {a }}$ & 9.93 & $<0.001$ & 9.04 & $<0.001$ \\
\hline Acanthomysis hwanhaiensis & - & - & - & - \\
\hline Alienacanthomysis macropsis & 14.21 & $<0.001$ & - & - \\
\hline Deltamysis holmquitae & 7.60 & 0.030 & 1.75 & 0.847 \\
\hline Neomysis kadiakensis & 12.20 & $<0.001$ & 12.05 & $<0.001$ \\
\hline Neomysis mercedis & -8.99 & $<0.001$ & -8.80 & $<0.001$ \\
\hline
\end{tabular}

rapid expansion of $C$. amurensis was likely facilitated by a prolonged period of low river inflow and a short-lived flood event that disturbed the local benthic community (Nichols et al. 1990). Concurrent with clam establishment, Chl- $a$ concentration dropped substantially below critical levels for zooplankton growth (Müller-Solger et al. 2002), and certain individual zooplankton species and mysids experienced a significant biomass decline. Mysids, historically a dominant contributor to the pelagic food web, dropped more than tenfold and their biomass constituted $<4 \%$ of total zooplankton after 1994. In the downstream suisun subregion, the contribution of calanoid and rotifer biomass dropped abruptly from a historical level of $60 \%$ to $<30 \%$ of total zooplankton biomass (excluding mysids) in 1992. This decline was compensated to some extent by the increase of cyclopoids.
In the upstream delta subregion, zooplankton biomass has remained at a low level since the mid-1980s.

The decline of many zooplankton species and mysids was likely related to food limitation and predation after the population expansion of the overbite clam $C$. amurensis in the mid 1980s (Fig. 11). Many zooplankton, including calanoids, rotifers, and mysids, compete with benthic suspension feeders for phytoplankton (Murrell and Hollibaugh 1998; Irigoien et al. 2003). The substantial drop in Chl- $a$ concentration below $10 \mu \mathrm{g} \mathrm{L}^{-1}$ after clam expansion suggested that the zooplankton was food-limited most of the time (Sobczak et al. 2002; Kimmerer et al. 2005). Reduced food availability for mysids was further suggested by the decreasing length of the mysid population as immature mysids depend on phytoplankton (Siegfried et al. 1979) and mysid growth is a 


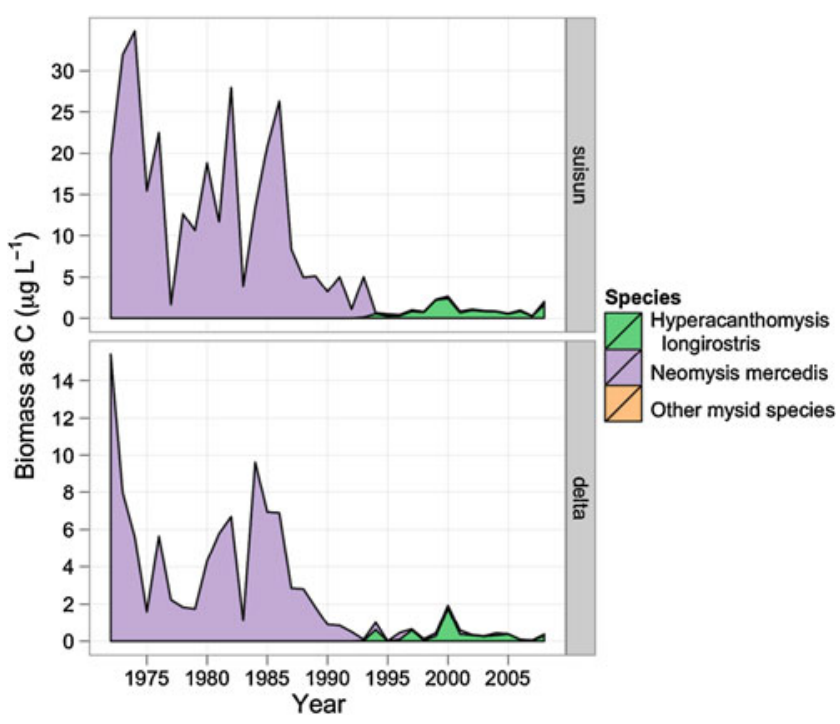

Fig. 9 Annual average biomass of mysids species by subregion (see Fig. 1) in the upper San Francisco Estuary between 1972 and 2008. H. longirostris was formerly classified as A. canthomysis bowmani; other mysids species include $A$. aspera, A. hwanhaiensis, Alienacanthomysis macropsis, Deltamysis holmquistae, Neomysis kadiakensis, and unidentified mysids. Top panel represents the "suisun" and bottom panel the "delta" subregion

function of food supply (Hansson et al. 1990). Moreover, the replacement of nutritious diatoms with small-sized flagellates and cyanobacteria (Lehman 2000; Kimmerer 2005) and increasing frequencies of Microcystis aeruginosa blooms (Lehman et al. 2008a, b) may have intensified the effect of the overall food limitation for primary consumers in

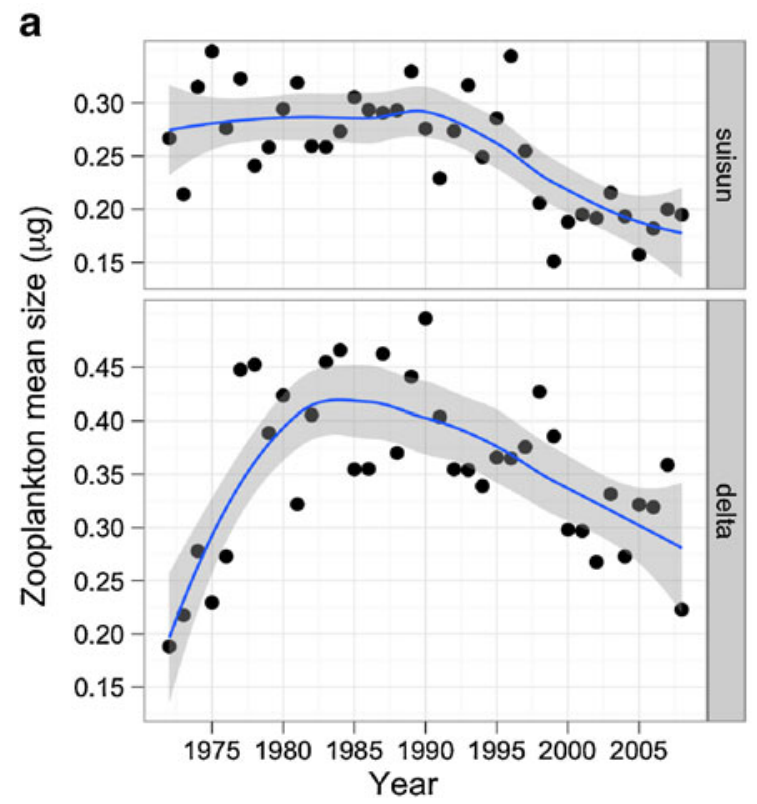

Fig. 10 Annual average zooplankton size by subregion (see Fig. 1) in the upper San Francisco Estuary between 1972 and 2008. a Mesozooplankton size (in $\mu \mathrm{g}$ ), including rotifers, cladocerans, cope- the upper Estuary (Ger et al. 2010). In addition to exploitative competition for shared food resources, direct clam predation on small-sized taxa and early life stages contributed to the declines in zooplankton. For instance, direct clam consumption was a major source of mortality for Eurytemora affinis naupliar stages (Kimmerer et al. 1994) and likely for other copepod nauplii. Clam consumption on nauplii is further suggested by the decreasing ratio of nauplii to adult abundance. Differential survival of adults and nauplii can also result from food limitation as the early ontogenetic stages are very sensitive to starvation and often a bottleneck in copepod development (Kiørboe and Sabatini 1995).

Declines of mysids and many zooplankton species were to some extent replaced by the establishment of $L$. tetraspina after the end of the prolonged drought period in 1992 (Fig. 11). The rapid expansion indicated that this invasive species was able to compensate for losses due to predation and to outcompete other zooplankton taxa. The success of this group was likely related to multiple characteristics: low metabolic demand, opportunistic feeding characteristics, and predator avoidance. The taxonomic group of this species (Oithonidae) is known for its high reproductive output (Turner 2004 and references within) and lower metabolic demands compared to calanoids of equivalent body weight (Castellani et al. 2005), owing to the low respiration rate and infrequent intermittent movement (Turner 2004). Furthermore, this species is a raptorial omnivore that feeds upon a wide range of particles and has the ability to exploit heterotrophic and autotrophic food

b

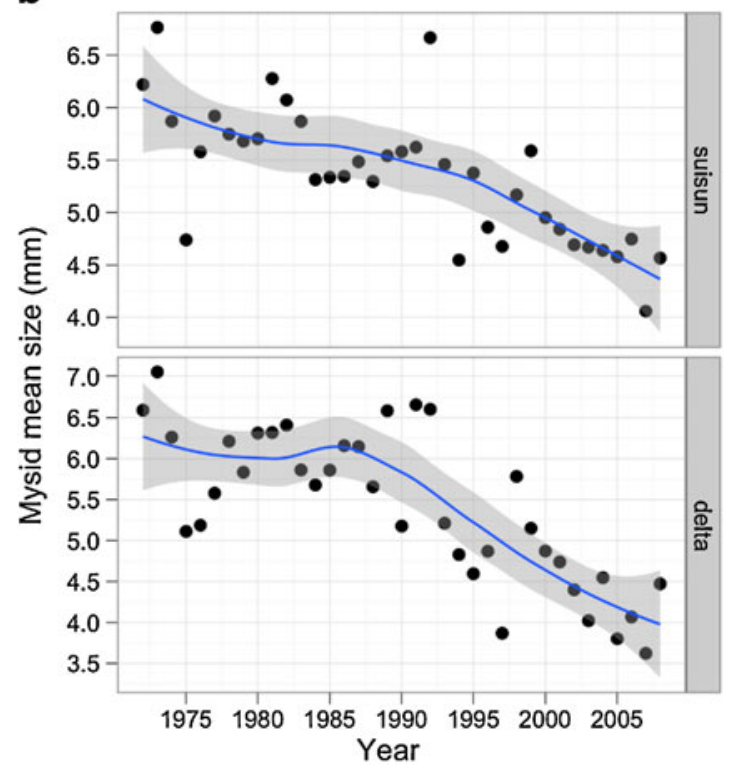

pods, and harpacticoids. b Averaged size of the mysids community. Top panels represent the "suisun" and bottom panels the "delta" subregion. The blue line displays a loess fit \pm standard error (shaded area) 


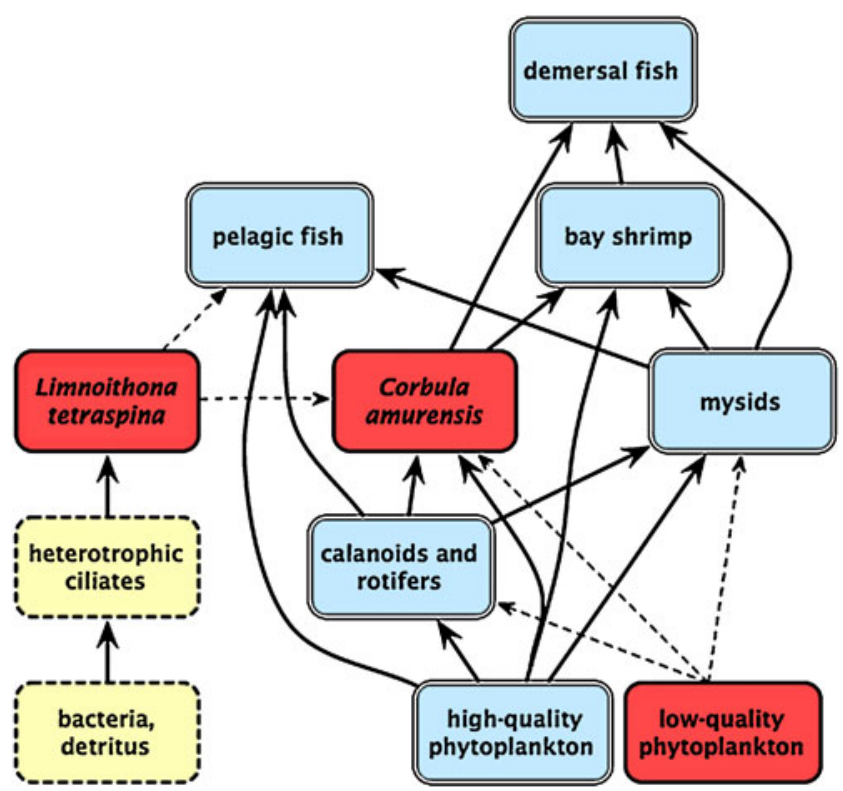

Fig. 11 Trophic interactions of the pelagic food web in the upper San Francisco Estuary at the "suisun" subregion. Arrows indicate major energy flow based on gut content analysis or literature data. Solid lines represent strong and dashed lines weak trophic interactions. Box colors reflect long-term taxa trends: red are increasing taxa, blue decreasing taxa, and yellow taxa of unknown trends over the last four decades. Phytoplankton is separated into groups of high (group I; e.g., diatoms) and low (group II; e.g., cyanobacteria, chlorophytes) food quality and/or availability for herbivorous organisms. Biomass trends for demersal fish and bay shrimp are adapted from Kimmerer (2006)

resources (Bouley and Kimmerer 2006). High bacterial production in the Delta and the phytoplankton change from diatoms to small-sized flagellates and cyanobacteria (Kimmerer 2004; Lehman et al. 2008a, b) likely favored L. tetraspina because small-sized phytoplankton stimulate microbial carbon cycling and heterotrophic and mixotrophic ciliates are an important diet source to meet the high biomass of this cyclopoid species (Bouley and Kimmerer 2006; Gifford et al. 2007; Gould and Kimmerer 2010). This is supported by the fact that L. tetraspina increased after 1994 even at low phytoplankton biomass. L. tetraspina is also relatively impervious to predation by some fish species (Bouley and Kimmerer 2006; Gould and Kimmerer 2010), and mysid declines reduced consumption of copepods. Furthermore, gelatinous zooplankton, their major predators in other estuaries, were abundant only occasionally in this estuary (Kimmerer 2004). Thus, alternate food supplies, reduced predation pressure, and life history attributes are likely reasons for the rapid increase and maintenance of high population biomass of this cyclopoid despite low primary production.

It can be expected that declines of many zooplankton species in the upstream delta subregion were caused by the same mechanism compared to the downstream suisun subregion, including competitive interactions for food with introduced clams, clam predation on early zooplankton life stages, and reduced phytoplankton quality (Kimmerer and Orsi 1996; Müller-Solger et al. 2002). This is supported by parallel changes at several trophic levels in both subregions in the mid-1980s. In addition, biotic interactions with introduced zooplankton species were potential factors that contributed to the strong declines of rotifers and cladocerans in the late 1970s. Declines of native taxa coincided with the invasion of $L$. sinensis and Sinocalanus doerrii; the latter is a carnivorous genus that feeds readily on rotifers, cladocerans, and nauplii (Hada and Uye 1991). In contrast to native diaptomids, cladocerans, and rotifers, Pseudodiaptomus spp. increased rapidly after its introduction in 1986 in the upstream region of the estuary and represented a third of the total zooplankton biomass after 1995. This genus was dominated by $P$. forbesi, which is an important prey for foraging fish and replaced $E$. affinis and $S$. doerrii after its establishment (Bryant and Arnold 2007). While the mechanisms for the successful growth and reproduction of Pseudodiaptomus spp. in the upstream estuary remain unknown, the selective feeding mode of this species may be advantageous in this system dominated by detrital and mineral particles. It has been shown that this calanoid selects high-quality phytoplankton (unpublished results from A. Müller-Solger, Department of Water Resources, Sacramento), whereas the less selective E. affinis or filterfeeding cladocerans may experience feeding interference with nutritionally inferior phytoplankton and detritus.

These observations indicate that long-term zooplankton community composition and biomass changes were strongly shaped by biotic interactions related to species invasions. Alternatively, increasing predation pressure, parasites, or diseases can cause declines in zooplankton. It is, however, unlikely that these top-down effects caused the abrupt drop in mysids and declines of many zooplankton species because planktivorous fish declined throughout the upper SF Estuary (Feyrer et al. 2007; Sommer et al. 2007), and parasites or diseases would be expected to act more speciesspecific.

\section{Effects of Zooplankton Changes on Fish Recruitment}

Alterations of the plankton community likely affected both the quantity and quality of zooplankton carbon for planktivorous fish and played an important role in the long-term decline and the more recent collapse of dominant pelagic fish species (Bennett and Moyle 1996). While the long-term decline of diverse fish populations in the upper SF Estuary coincided with reduced primary and secondary production (Cloern 2007), our analysis showed that the sudden drop of many pelagic fishes in 2002 (Sommer et al. 2007; Thomson et al. 2010) was not accompanied by an equivalent decrease in the quantity of zooplankton carbon. 
Substantial zooplankton and mysid declines occurred in the mid- to late $1980 \mathrm{~s}$, and biomass of both groups remained at low levels thereafter, without significant changes in the early 2000s when pelagic fish densities dropped substantially (Table 2 ). This suggests that changing prey quantity was not a dominant factor contributing to the recent fish declines. However, it is suspected that the persistence of an overall low food supply, combined with changing prey composition resulting from zooplankton taxonomic shifts, enhanced food limitations for estuarine-dependent fish (Fig. 11)

The collapse of mysids was likely a substantial loss of a nutritious food resource that affected recruitment of many fish species, such as striped bass (Feyrer and Healey 2003; Nobriga and Feyrer 2008). Mysids were historically the preferred prey item for juvenile and adult life stages of this fish, and likely other fish species, and dietary shifts to alternate prey may not have fully replaced mysid nutritional and energetic content (Kimmerer 2000; Nobriga and Feyrer 2008). Furthermore, the shift from a rotifer- and calanoiddominated community (Fig. 11) to a cyclopoid-dominated community was most likely accompanied by a shift in the nutritional quality of zooplankton carbon for fish because cyclopoids and calanoids utilize different food sources. Calanoids prey primarily on highly nutritious phytoplankton (Gifford et al. 2007), such as diatoms and cryptophytes (Brett and Müller-Navarra 1997), whereas L. tetraspina capitalizes mainly on ciliates that prey on bacteria (Bouley and Kimmerer 2006). Compared to phytoplankton, bacterial-derived organic matter is a nutritionally impoverished food resource (Klein Breteler et al. 2004, Brett et al. 2009) because bacteria lack high-quality lipids essential for fish larval survival. Although some heterotrophic protists are able to upgrade the nutritional value of bacteria (Martin-Creuzburg et al. 2004), ciliates are generally incapable of synthesizing essential lipids for copepod growth (Klein Breteler et al. 2004). However, the biochemical capabilities of ciliates are highly species-specific (Martin-Creuzburg et al. 2004), and the role of protists as an intermediary within the food chain for higher trophic levels remains to be investigated in this estuary. Nevertheless, it can be expected that fish benefit by consuming calanoids as organic matter enters the metazoan food web at a higher trophic efficiency compared to zooplankton that feed on the microbial food web (Sobczak et al. 2002). In addition, a smaller-sized zooplankton community combined with the dominance of omnivorous cyclopoids implies that the pelagic food web was largely driven by recycled carbon after 1994 as small-sized copepods stimulate carbon recycling through the microbial food web (Havens 1998). Consequently, the change in zooplankton community structure was likely accompanied by a shift in the energy pathway from a phytoplankton-based to a detrital-based pelagic food web (Klein Breteler et al. 2004; Brett et al. 2009), and the zooplankton biomass increase in suisun after 1993 likely resulted in poorer food quality for fish. However, the reduced flow of high-quality carbon from phytoplankton up the food web may not have effects on community biomass for zooplankton because this dissolved organic carbon-rich system now supports high biomass of copepods such as L. tetraspina that can subsist on the microbial food web.

In addition to reduced food quality, the significant drop in zooplankton size is another attribute affecting prey availability for fish. Smaller-sized prey reduce the catchability of visually oriented planktivores, increasing handling time and consequently reducing the energetic intake of fish (Winfield and Townsend 1983). In addition, the sedentary behavior of $L$. tetraspina leads to less attack rates and, combined with the small size, renders them less susceptible to predation by fish. This small-sized cyclopoid comprised only a small proportion of delta smelt's diet, a visual predator, despite its abundance (Bouley and Kimmerer 2006), indicating that this cyclopoid is not a preferred prey item and probably a dead end energetically in the upper SF Estuary's food web (Bouley and Kimmerer 2006). Nauplii, the other abundant small-sized group in the mesohaline region, can be an important prey source for larval fish (Turner 2004 and references therein), but the role of nauplii and their contribution to higher trophic levels remain unknown in the food web of this estuary. Overall, combined with the selective feeding mode of fish, it can be speculated that the dominance of small-sized cyclopoids reduced prey quality attributes, including foraging efficiency and the nutritional value of zooplankton for fish. Low food supply combined with changing food quality likely translated into reduced growth and survival of pelagic fish and affected their long-term and more recent recruitment success.

A remarkable feature of the zooplankton assemblage throughout the Sacramento-San Joaquin Delta and Suisun Bay was the displacement of the local fauna with introduced species, particularly with regard to copepods and mysids. The timing of introduction coincided with persistent (multi-year) low-water inflow, particularly with the beginning or end of droughts that resulted in elevated salinity. These observations suggest that prolonged climate anomalies may open a window for nonindigenous species to establish and eventually displace the local fauna. The precise mechanisms allowing the establishment of invasive zooplankton species in this estuary remain to be investigated. Nevertheless, our study showed that species invasion resulted in decadal changes in the zooplankton community composition that strongly affected secondary production and food quantity and quality for pelagic consumers in the San Francisco 
Estuary. The unpredictability and strong impacts of these invasions complicate the long-term management of estuarine ecosystems.

Acknowledgments We thank April Hennessey and Kathy Hieb for providing the data and Anke Müller-Solger and Wim Kimmerer for providing biomass conversion factors. Figure 1 is based on a map originally drawn by Jeanne Dileo. Wim Kimmerer, Jim Cloern, and three anonymous reviewers are thanked for valuable comments. Financial support by the CALFED Science Program under grant no. R/SF-36 (CalFed U-04-SC-005), State Water Contractors and San Luis and Delta-Mendota Water Authority, and the Interagency Ecological Program under California DWR agreement no. 4600008137 T5 is gratefully acknowledged.

Open Access This article is distributed under the terms of the Creative Commons Attribution Noncommercial License which permits any noncommercial use, distribution, and reproduction in any medium, provided the original author(s) and source are credited.

\section{References}

Allen, D.M., V. Ogburn Matthews, T. Buck, and E.M. Smith. 2008. Mesozooplankton responses to climate change and variability in a Southeastern U.S. Estuary (1981-2003). Journal of Coastal Research 55: 95-110.

Almeda, R., C.B. Augustin, M. Alcaraz, A. Calbet, and E. Saiz. 2010. Feeding rates and gross growth efficiencies of larval developmental stages of Oithona davisae (Copepoda, Cyclopoida). Journal of Experimental Marine Biology and Ecology 387: 24-35.

Alpine, A.E., and J.E. Cloern. 1992. Trophic interactions and direct physical effects control phytoplankton biomass and production in an estuary. Limnology and Oceanography 37: 946-955.

Baxter, R., R. Breuer, M. Chotkowski, F. Feyrer, M. Gingras, B. Herbold, A. Müller-Solger, M. Nobriga, T. Sommer, and K. Souza. 2007. Pelagic Organism Decline Progress Report: 2007 Synthesis of Results. Sacramento: Interagency Ecological Program for the San Francisco Estuary. http://www.fws.gov/ sacramento/es/documents/POD_report_2007.pdf.

Bennett, W.A., and P.B. Moyle. 1996. Where have all the fishes gone? Interactive factors producing fish declines in the Sacramento-San Joaquin Estuary. In San Francisco Bay: The ecosystem, ed. J.T. Hollibaugh, 519-542. San Francisco: Pacific Division of the American Association for the Advancement of Science.

Bouley, P., and W.J. Kimmerer. 2006. Ecology of a highly abundant, introduced cyclopoid copepod in a temperate estuary. Marine Ecology Progress Series 324: 219-228.

Brett, M.T., and D.C. Müller-Navarra. 1997. The role of highly unsaturated fatty acids in aquatic food web processes. Freshwater Biology 38: 483-499.

Brett, M.T., M.J. Kainz, S.M. Taipalea, and H. Seshana. 2009. Phytoplankton, not allochthonous carbon, sustains herbivorous zooplankton production. Proceedings of the National Academy of Science (USA) 106: 21197-21201.

Bryant, M.E., and J.D. Arnold. 2007. Diets of age-0 striped bass in the San Francisco Estuary, 1973-2002. California Fish and Game 93: 1-22.

CALFED. 2001. CALFED Annual Report 2001. Sacramento: CALFED Bay-Delta Program. http://calwater.ca.gov/calfed/ library/Annual Reports.html.
Carlton, J.T., J.K. Thompson, L.E. Schemel, and F.H. Nichols. 1990. Remarkable invasion of San-Francisco Bay (California, USA) by the Asian clam Potamocorbula amurensis. I. Introduction and dispersal. Marine Ecology Progress Series 66: 81-94.

Castellani, C., C. Robinson, T. Smith, and R.S. Lampitt. 2005. Temperature affects respiration rate of Oithona similis. Marine Ecology Progress Series 285: 129-135.

Cloern, J.E. 2007. Habitat connectivity and ecosystem productivity: Implications from a simple model. The American Naturalist 169: E21-E33.

Cloern, J.E., and F.H. Nichols. 1985. Temporal dynamcis of an estuary: San Francisco Bay. Dordrecht: Kluwer.

Cohen, A.N., and J.T. Carlton. 1998. Accelerating invasion rate in a highly invaded estuary. Science 279: 555-558.

Costello, J.H., B.K. Sullivan, and D.J. Gifford. 2006. A physicalbiological interaction underlying variable phenological responses to climate change by coastal zooplankton. Journal of Plankton Research 28: 1099-1105.

Dumont, H.J., I. Van de Velde, and S. Dumont. 1975. The dry weight estimate of biomass in a selection of Cladocera, Copepoda and Rotifera from the plankton, periphyton and benthos of continental waters. Oecologia 19: 75-97.

Durbin, E.G., and A.G. Durbin. 1978. Length and weight relationships of Acartia clausi from Narragansett Bay, R.I. Limnology and Oceanography 23: 958-969.

Feyrer, F., and M.P. Healey. 2003. Fish community structure and environmental correlates in the highly altered southern SacramentoSan Joaquin Delta. Environmental Biology of Fishes 66: 123-132.

Feyrer, F., M. Nobriga, and T. Sommer. 2007. Multi-decadal trends for three declining fish species: Habitat patterns and mechanisms in the San Francisco Estuary, California, U.S.A. Canadian Journal of Fisheries and Aquatic Sciences 64: 723-734.

Fofonoff, N.P., and R.C. Millard. 1983. Algorithms for computations of fundamental properties of seawater. UNESCO Technical Papers in Marine Science 44. Paris: UNESCO Division of Marine Sciences.

Ger, K.A., S.J. Teh, D.V. Baxa, S. Lesmeister, and C.R. Goldman. 2010. The effects of dietary Microcystis aeruginosa and microcystin on the copepods of the upper San Francisco Estuary. Freshwater Biology 55: 1548-1559.

Gifford, S.M., G. Rollwagen-Bollens, and S.M. Bollens. 2007. Mesozooplankton omnivory in the upper San Francisco Estuary. Marine Ecology Progress Series 348: 33-46.

Gould, A., and W. Kimmerer. 2010. Development, growth, and reproduction of the cyclopoid copepod Limnoithona tetraspina in the upper San Francisco Estuary. Marine Ecology Progress Series 412: 163-177.

Hada, A., and S. Uye. 1991. Cannibalistic feeding-behavior of the brackish-water copepod Sinocalanus tenellus. Journal of Plankton Research 13: 155-166.

Hansson, S., L.G. Rudstam, and S. Johansson. 1990. Are marine planktonic envertebrates food limited? The case of Mysis mixta (Crustacea, Mysidacea). Oecologia 84: 430-432.

Havens, K.E. 1998. Size structure and energetics in a plankton food web. Oikos 81: 346-358.

Helsel, D.R., and R.M. Hirsch. 1992. Statistical methods in water resources. Amsterdam: Elsevier Science.

Hill, K.D., T.M. Dauphinee, and D.J. Woods. 1986. The extension of the practical salinity scale 1978 to low salinities. IEEE Journal of Oceanic Engineering 11: 109-112.

Houde, E.D., and E.S. Rutherford. 1993. Recent trends in estuarine fisheries-Predictions of fish production and yield. Estuaries 16: $161-176$. 
IEP. 2006. Dayflow Documentation. Sacramento: Interagency Ecological Program for the San Francisco Estuary. http://www.water.ca.gov/ dayflow/documentation/.

Irigoien, X., J. Titelman, R.P. Harris, D. Harbour, and C. Castellani. 2003. Feeding of Calanus finmarchicus nauplii in the Irminger Sea. Marine Ecology Progress Series 262: 193-200.

Jassby, A.D. 2008. Phytoplankton in the Upper San Francisco Estuary: Recent biomass trends, their causes and their trophic significance. San Francisco Estuary and Watershed Science 6:Article 2.

Jassby, A.D., and J.E. Cloern. 2000. Organic matter sources and rehabilitation of the Sacramento-San Joaquin Delta (California, USA). Aquatic Conservation-Marine and Freshwater Ecosystems 10: 323-352.

Jassby, A.D., J.E. Cloern, and T.M. Powell. 1993. Organic-carbon sources and sinks in San-Francisco Bay-Variability induced by river flow. Marine Ecology Progress Series 95: 39-54.

Jassby, A.D., J.E. Cloern, and B.E. Cole. 2002. Annual primary production: Patterns and mechanisms of change in a nutrient-rich tidal ecosystem. Limnology and Oceanography 47: 698-712.

Kimmel, D.G., and M.R. Roman. 2004. Long-term trends in mesozooplankton abundance in Chesapeake Bay, USA: Influence of freshwater input. Marine Ecology Progress Series 267: 71-83.

Kimmerer, W.J. 2000. Analysis of an estuarine striped bass (Morone saxatilit) population: Influence of density-dependent mortality between metamorphosis and recruitment. Canadian Journal of Fisheries and Aquatic Science 57: 478-486.

Kimmerer, W.J. 2002. Effects of freshwater flow on abundance of estuarine organisms: Physical effects or trophic linkages? Marine Ecology Progress Series 243: 39-55.

Kimmerer, W. 2004. Open water processes of the San Francisco Estuary: From physical forcing to biological responses. San Francisco Estuary and Watershed Science 2: 1-142.

Kimmerer, W. 2005. Long-term changes in apparent uptake of silica in the San Francisco estuary. Limnology and Oceanography 50: 793-798.

Kimmerer, W.J. 2006. Response of anchovies dampens effects of the invasive bivalve Corbula amurensis on the San Francisco Estuary foodweb. Marine Ecology Progress Series 324: 207-218.

Kimmerer, W.J., and J.J. Orsi. 1996. Changes in the zooplankton of the San Franscisco Bay Estuary since the introduction of the clam Potamocorbula amurensis. In San Francisco Bay: The eosystem, ed. J.T. Hollibaugh, 403-424. San Francisco: Pacific Division of the American Association for the Advancement of Science.

Kimmerer, W.J., E. Gartside, and J.J. Orsi. 1994. Predation by an introduction clam as the likely cause of substantial declines in zooplankton of San-Francisco Bay. Marine Ecology Progress Series 113: 81-93.

Kimmerer, W.J., N. Ferm, M.H. Nicolini, and C. Penalva. 2005. Chronic food limitation of egg production in populations of copepods of the genus Acartia in the San Francisco Estuary. Estuaries 28: 541-550.

Kiørboe, T., and T.G. Nielsen. 1994. Regulation of zooplankton biomass and production in a temperate, coastal ecosystem. 1 . Copepods. Limnology and Oceanography 39: 493-507.

Kiørboe, T., and M. Sabatini. 1995. Scaling of fecundity, growth and development in marine planktonic copepods. Marine Ecology Progress Series 120: 285-298.

Klein Breteler, K., W.C.M. Koski, and S. Rampen. 2004. Role of essential lipids in copepod nutrition: No evidence for trophic upgrading of food quality by a marine ciliate. Marine Ecology Progress Series 274: 199-208.

Lehman, P.W. 2000. Phytoplankon biomass, cell diameter, and species composition in the low salinity zone of northern San Francisco Bay estuary. Estuaries 23: 216-230.
Lehman, P.W., G. Boyer, M. Satchwell, and S. Waller. 2008a. The influence of environmental conditions on the seasonal variation of Microcystis cell density and microcystins concentration in San Francisco Estuary. Hydrobiologia 600: 187-204.

Lehman, P.W., T. Sommer, and L. Rivard. 2008b. The influence of floodplain habitat on the quantity and quality of riverine phytoplankton carbon produced during the flood season in San Francisco Estuary. Aquatic Ecology 42: 363-378.

Lonsdale, D.J., and B.C. Coull. 1977. Composition and seasonality of zooplankton of North Inlet, South Carolina. Chesapeake Science 18: 272-283.

Martin-Creuzburg, D., A. Bec, and E. Von Elert. 2004. Trophic upgrading of picocyanobacterial carbon by ciliates for nutrition of Daphnia magna. Aquatic Microbial Ecology 41: 271-280.

Moyle, P.B. 2002. Inland fishes of California. Berkeley: University of California Press.

Müller-Solger, A.B., A.D. Jassby, and D.C. Müller-Navarra. 2002. Nutritional quality of food resources for zooplankton (Daphnia) in a tidal freshwater system (Sacramento-San Joaquin River Delta). Limnology and Oceanography 47: 1468-1476.

Murrell, M.C., and J.T. Hollibaugh. 1998. Microzooplankton grazing in northern San Francisco Bay measured by the dilution method. Aquatic Microbial Ecology 15: 53-63.

Nichols, F.H., J.K. Thompson, and L.E. Schemel. 1990. Remarkable invasion of San-Francisco Bay (California, USA) by the Asian clam Potamocorbula amurensis. 2. Displacement of a former community. Marine Ecology Progress Series 66: 95-101.

Nobriga, M.L., and F. Feyrer. 2008. Diet composition in San Francisco Estuary striped bass: Does trophic adaptability have its limits? Environmental Biology of Fishes 83: 509-517.

Orsi, J.J., and W.L. Mecum. 1986. Zooplankton distribution and abundance in the Sacramento-San Joaquin Delta in relation to certain environmental factors. Estuaries 9: 326-339.

Orsi, J.J., and S. Ohtsuka. 1999. Introduction of the Asian copepods Acartiella sinensis, Tortanus dextrilobatus (Copepoda: Calanoida), and Limnoithona tetraspina (Copepoda: Cyclopoida) to the San Francisco Estuary, California, USA. Plankton Biology Ecology 46: $128-131$.

Paerl, H.W., L. Karen, S. Rossignol, N. Hall, B.L. Peierls, and M.S. Wetz. 2010. Phytoplankton community indicators of short- and long-term ecological change in the anthropogenically and climatically impacted Neuse River Estuary, North Carolina, USA. Estuaries and Coasts 33: 485-497.

Pauli, H.R. 1989. A new method of estimating individual dry weights of rotifers. Hydrobiologia 186: 355-361.

Petersen, J.K., J. Würgler Hansen, M. Brogaard Laursen, P. Clausen, J. Carstensen, and D.J. Conley. 2008. Regime shift in a coastal marine ecosystem. Ecological Applications 18: 497-510.

R Development Core Team. 2009. R: A language and environment for statistical computing. Vienna: R Foundation for Statistical Computing. ISBN 3-900051-07-0. http://www.R-project.org.

Siegfried, C.A., M.E. Kopache, and A.W. Knight. 1979. The distribution and abundance of Neomysis mercedis in relation to the entrapment zone in the western Sacramento-San Joaquin Delta. Transactions of the American Fisheries Society Symposium 108: 262-268.

Sobczak, W.V., J.E. Cloern, A.D. Jassby, and A.B. Müller-Solger. 2002. Bioavailability of organic matter in a highly disturbed estuary: The role of detrital and algal resources. Proceedings of the National Academy of Sciences of the United States of America 99: 8101-8105.

Sommer, T., C. Armor, R. Baxter, R. Breuer, L. Brown, M. Chotkowski, S. Culberson, F. Feyrer, M. Gingras, B. Herbold, 
W. Kimmerer, A. Müller-Solger, M. Nobriga, and K. Souza. 2007. The collapse of pelagic fishes in the Upper San Francisco Estuary. Fisheries 32: 270-277.

Thomson, J.R., W.J. Kimmerer, L.R. Brown, K.B. Newman, R. Mac Nally, W.A. Bennett, F. Feyrer, and E. Fleishman. 2010. Bayesian change point analysis of abundance trends for pelagic fishes in the upper San Francisco Estuary. Ecological Applications 20: 1431-1448.

Turner, J.T. 2004. The importance of small planktonic copepods and their roles in pelagic marine food webs. Zoological Studies 43: 255-266.

Uye, S.I. 1982. Length-weight relationships of important zooplankton from the Inland Sea of Japan. Journal of the Oceanographical Society of Japan 38: 149-158.
Verity, P.G., and D.G. Borkman. 2010. A decade of change in the Skidaway River Estuary. III. Plankton. Estuaries and Coasts 33: 513-540.

Verity, P.G., and V. Smetacek. 1996. Organism life cycles, predation, and the structure of marine pelagic ecosystems. Marine Ecology Progress Series 130: 277-293.

Winfield, I.J., and C.R. Townsend. 1983. The cost of copepod reproduction: Increased susceptibility to fish predation. Oecologia 60: 406-411.

Zervoudaki, S., T.G. Nielsen, and J. Carstensen. 2009. Seasonal succession and composition of the zooplankton community along an eutrophication and salinity gradient exemplified by Danish waters. Journal of Plankton Research 31: 1475-1492. 